\title{
SEJARAH HUKUM KEDUDUKAN PEREMPUAN DALAM PERKAWINAN MENURUT HUKUM ADAT BALI (KAITANNYA DENGAN PERKAWINAN NYENTANA BEDA WANGSA) ${ }^{1}$
}

\author{
Oleh : \\ Ni Nengah Budawati ${ }^{2}$
}

\begin{abstract}
This study aimed to know and understand about the legal culture of community on the phenomenon of different caste nyentana marriage. This research was empirical legal research legal research with behavioral approaches. The data source consisted of primary data sourced directly at the site of research and secondary data that included legislation, traditional laws, law books, magazines, dictionaries and newspapers. This study used qualitative data analysis which then produced descriptive data.Based on the national legal perspective, there are no differences in the position of husband and wife in different caste nyentana marriage. But in Balinese customary law, it resulted in the wife having a position that is more important than the husband in the family. As in the context of social life, especially in the capacity as krama in the sub-village, then the husband remains responsible for his obligations as krama muani while the wife still serves as krama luh. Related to the legal culture of indigenous people in Tabanan over different caste nyentana marriage, the fact that people are still of the view that marriage is an inter-caste marriage. Thus the legal culture of indigenous people in Tabanan tends to be static. This is motivated by many factors, one of which is either ignorance factor of traditional leaders or traditional krama of Decree of the Parliament No. 11 of 1951 which expressly has abolished inter-caste marriages that often lead to discrimination.
\end{abstract}

Keywords: Culture Law, different caste Nyentana,Wangsa.

\begin{abstract}
Abstrak
Penelitian ini bertujuan untuk mengetahui dan memahami tentang budaya hukum masyarakat terhadap fenomena hukum perkawinan nyentana beda wangsa. Penelitian ini ialah penelitian hukum penelitian hukum empiris dengan pendekatan pendekatan prilaku (behavioral approach). Sumber data terdiri dari data primer yang bersumber langsung di lokasi penelitian dan data sekunder yang meliputi peraturan perundang-undangan, awig-awig, buku-buku hukum, majalah, kamus dan surat kabar. Penelitian ini menggunakan analisis data secara kualitatif yang kemudian menghasilkan data deskriptif. Berdasarkan perspektif hukum secara nasional, tidak terdapat perbedaan sejarah kedudukan suami-isteri

1 Artikel ini merupakan karya ilmiah mahasiswa pada Program Studi Magister (S2) Ilmu Hukum Program Pascasarjana Universitas Udayana dan mengucapkan terimakasih kepada Prof. Dr. I Wayan Windia, SH.,M.Si dan Dr. I Ketut Sudantra, SH.,MH selaku Pembimbing Tesis

2 Mahasiswa Magister Ilmu Hukum Universitas Udayana, Denpasar, Bali, e-mail : kadek.buda@yahoo. com.
\end{abstract}


dalam perkawinan nyentana beda wangsa. Namun dalam Hukum adat Bali, justru mengakibatkan istri memiliki kedudukan yang lebih penting dibanding suami di dalam keluarga. Adapun dalam konteks kehidupan bermasyarakat, khususnya dalam kapasitas sebagai krama di banjar, maka si suami tetap bertanggung jawab pada kewajibannya sebagai krama muani sedangkan si istri tetap berkedudukan sebagai krama luh. Terkait dengan budaya hukum masyarakat hukum adat di Tabanan terhadap perkawinan nyentana beda wangsa, faktanya masyarakat tetap berpandangan bahwa perkawinan tersebut merupakan perkawinan antar kasta. Dengan demikian budaya hukum masyarakat hukum adat di Tabanan cenderung bersifat statis. Hal ini dilatarbelakangi oleh banyak faktor, salah satu diantaranya ialah faktor ketidaktahuan baik dari pemuka adat maupun krama adat tentang Keputusan DPRD No. 11 Tahun 1951 yang secara tegas telah menghapus perkawinan antar kasta yang kerap menimbulkan diskriminasi.

Kata kunci : Budaya Hukum, Nyentana beda wangsa,Wangsa.

\section{PENDAHULUAN}

\subsection{Latar Belakang}

MasyarakatBalimerupakansalah satu masyarakat yang menganut sistem kekeluargaan purusa (patrilinial). Dalam tertib hukum masyarakat patrilineal, bentuk perkawinan yang dianut adalah bentuk perkawinan di mana istri ikut suami. Di Bali, bentuk perkawinan ini disebut nganten biasa. Berbeda dengan perkawinan biasa, dalam perkawinan nyeburin mempelai perempuan tetap menetap sebagai bagian keluarga asalnya, berstatus sebagai purusa. Justru, dalam nyeburin mempelai laki-laki yang meninggalkan keluarga asalnya untuk selanjutnya masuk menjadi bagian dari keluarga istrinya. Dalam perkawinan ini, mempelai perempuan yang berstatus sentana rajeg itu berkedudukan sebagai purusa yang mempunyai hak dan kewajiban sama dengan lakilaki di keluarga tersebut, sedangkan suaminya berstatus sebagai pradana, sebagaimanan layaknya status perempuan (istri) dalam perkawinan biasa $^{3}$.

Salah satu permasalahan dalam hukum perkawinan yang sering muncul adalah permasalahan perkawinan yang terkait dengan sistem pelapisan sosial berdasarkan keturunan yang masih kuat dianut dalam masyarakat Bali. Bebepara kalangan menyebut sistem pelapisan sosial tersebut dengan istilah "wangsa" sedangkan pihak lain menyebut dengan istilah "kasta". Menurut Ketut Wiana dan Raka Santeri, sistem pelapisan sosial yang berlaku dalam masyarakat Hindu di Bali adalah "wangsa". Menurut Wiana dan Raka Santri, masyarakat Bali dalam kenyataannya sekarang dibagi dalam tiga golongan yang disebut tri wangsa, yaitu:

1. Golongan pertama adalah
golongan Brahmana, yaitu
golongan masyarakat yang
secara tradisional berasal
dari ketuirunan Danghyang
$\frac{\text { Ibid., hlm.. 8. }}{}$


Dwijendra (Brahmanan Siwa) dan Danghyang Astapaka (Brahmana Budha). Umumnya rumah golongan Brahmana ini disebut Geria.

2. Golongan kedua adalah golongan Ksatria, yaitu golongan yang berasal dari keturunan para kesatria yang berasal dari Kediri dan Majapahit. Rumah dari golongan ini disebut Jero atau Puri.

3. Golongan ketiga adalah golongan $J a b a$, yaitu golongan masyarakat yang merupakan keturunan masyarakat kebanyakan yang bertempat tinggal di luar (luar = jaba) Jero, Puri, atau Geria ${ }^{4}$

Sistem pelapisan sosial ini menimbulkan permasalahan dalam perkawinan sebab dalam perkawinan dianut asas kesederajatan dalam wangsa (pepadan) dan sangat dihindari perkawinan yang tidak sederajat dalam hal wangsa (beda wangsa), terutama dalam hal wangsa pihak laki-laki (purusa) lebih rendah dibandingkan dengan mempelai perempuan (pradana).

Namun demikian, ada hal yang menarik dari fenomena perkawinan beda wangsa yaitu apabila dikaitkan dengan bentuk perkawinan nyentana (nyeburin). Sangat sedikit terjadi kasus perkawinan nyentana di mana mempelai laki-laki mempunyai

Ketut Wiana dan Raka Santri, 1993, Kasta dalam Hindu Kesalahpahaman Berabadabad, Yayasan Dharma Naradha, Denpasar, hlm. 22. kedudukan wangsa yang lebih rendah daripadawangsamempelaiperempuan. I Nyoman Budiana menyebutkan perkawinan nyentana model ini hanya dapat ditemui di beberapa desa di kabupaten Tabanan, yaitu Desa Penarukan dan Desa Wanasari ${ }^{5}$. Di samping jumlahnya sedikit, hasil penelitian terdahulu juga menunjukkan bahwa perkawinan nyentana model ini masih menimbulkan persoalan sosiologis, yaitu tidak diterima oleh kalangan masyarakat tertentu.

Terdapat penelitian lainnya terkait penelitian beda wangsa. Seperti dapat dilihat dari hasil penelitian I Ketut Wirta Griadhi dan kawan-kawan (1992), kasus penolakan masyarakat (kelompok warga Brahmana) terhadap perkawinan nyentana beda wangsa di manamempelailaki-lakiberkedudukan wangsa lebihrendah terjadi di Wanasari tahun 1984. Dalam kasus ini terjadi perkawinan nyentana (nyeburin) beda wangsa di mana wangsa mempelai perempuan lebih tinggi (Brahmana Wangsa) dibandingkan dengan wangsa mempelai laki-laki (Jaba). Perkawinan itu sendiri dinyatakan sah oleh Pengadilan (Putusan Pengadilan Negeri Tabanan No. 8/Pdt.P/1985/ PN. Tbn), tetapi dalam kenyataannya perkawinan tersebut tetap ditolak oleh masyarakat, terutama dari pihak keluarga besar mempelai perempuan ${ }^{6}$.

\footnotetext{
$5 \quad$ Ibid., hlm.33.

$6 \quad$ IKetut Wirta Griadhi, et all., 1992, "Perkawinan Nyeburin Berbeda Wangsa: Studi Antropologi Hukum Terhadap Kasus di Desa Wanasasri dan Desa Berembeng Kabupaten Tabanan”, Laporan Penelitian, Universitas Udayana, Denpasar, hlm. 15.
} 
Dari kasus Wanasari tersebut dapat disimpulkan bahwa masih ada permasalahan pada aspek budaya hukum masyarakat dalam menyikapi perkawinan nyentana beda wangsa ini. Dilihat dari aspek hukum (substansi hukum), perkawinan demikian adalah sah secara hukum sehingga tidak ada persoalan dari segi yuridis. Walaupun sah secara hukum, tetapi model perkawinan nyentana beda wangsa di mana wangsa mempelai laki-laki lebih rendah dari mempelai perempuan dalam kenyataan tidak diterima oleh masyarakat sehingga masih menjadi persoalan sosiologis. Dengan demikian, dalam kasus di atas masih terjadi gap (kesenjangan) antara kaedah hukum (das sollen) dengan sikap masyarakat (das sein) terhadap hukum dalam hal perkawinan beda wangsa ini.

\subsection{Perumusan Masalah}

Berdasarkan atas latar belakang masalah maka dapat dirumuskan permasalahan sebagai berikut :

1. Bagaimana sejarah kedudukan hukum suami istri yang melakukan perkawinan nyentana beda wangsa dalam keluarga dan masyarakat?

2. Bagaimana budaya hukum masyarakat hukum adat Bali terhadap perkawinan nyentana beda wangsa dikaitkan dengan kedudukan perempuan dalam perkawinan tersebut?

\subsection{Landasan Teoritis Dan Kerangka Berpikir \\ 1.3.1 Landasan Teoritis}

Teori yang akan dipergunakan untuk menganalisa permasalahan yang dihadapi dalam penelitian bentuk perkawinan nyentana beda wangsa sebanyak 2 (dua) teori. Adapun teoriteori tersebut adalah :

\subsection{Teori semi Autinomous Social Field \\ Teori ini dikemukakan oleh} Sally Falk Moore . Inti Teorinya adalah bahwa dalam ajaran mengenai Pluralisme Hukum (Legal Pluralism) keberadaandaribeberapasistemhukum ( hukum agama, hukum kebiasaan dan juga mekanisme-mekanis pengaturan local) secara empiris berlangsung dalam kehidupan masyarakat adalah merupakan hukum.

\section{2 Teori Sistem Hukum \\ Teori Sistem Hukum} dikemukakan oleh Lawrence M. Friedman akan digunakan untuk membahas permasalahan terkait dengan budaya hukum masyarakat terhadap perkawinan nyentana beda wangsa dan factor-faktor yang mempengaruhi masyarakat menolak atau menerima perkawinan nyentana beda wangsa.. Inti dari teori ini adalah untuk dapat kerja secara efektif, hukum sebagai suatu sistem harus memenuhi 3 (tiga) elemen pokok, yaitu struktur sistem hukum (structure of legal), substansi sistem hukum (substance 
of legal system), dan budaya hukum masyarakat (legal culture).

\section{METODE PENELITIAN}

2.1 Jenis Penelitian

Penelitian initermasuk penelitian hukum empiris, yaitu penelitian yang bertujuan untuk melukiskan fenomena hukum di dalam masyarakat.

\subsection{Sifat Penelitian}

Penelitian ini bersifat dekriptif analitis yaitu Sifat penelitian yang bertujuan menggambarkan secara tepat sifat-sifat suatu individu atau kelompok tertentu, keadaan, gejala, atau untuk menentukan ada tidaknya hubungan antara suatu gejala dengan gejala yang lain.

\subsection{Jenis Pendekatan}

Sesuai dengan bidang penelitian hukum, maka pendekatan masalah yang dapat digunakan adalah pendekatan prilaku (behavioral approach). ${ }^{7}$ Pendekatan-pendekatan yang dipergunakan dalam penelitian ini meneliti tentang budaya masyarakat mengenai perkawinan nyentana beda wangsa.

\subsection{Lokasi Penelitian}

Dalam rangka memperoleh data pada penulisan ini, penulis menentukan lokasi penelitian dengan kriteriakriteria sebagai berikut :

(a) Lokasi dimana daerah tersebut pernah melangsungkan perkawinan nyentana beda wangsa (b) Lokasidimana dalamperkawinan beda wangsa tersebut, wangsa mempelai laki-laki lebih rendah dari pada yang perempuan.

Sehinggadengan memperhatikan kriteria-kriteria tersebut ditentukan lokasi penelitiannya adalah Dusun tengah, Desa Wanasari, Kecamatan Tabanan, Kabupaten Tabanan.

\subsection{Sumber Data}

Data yang digunakan dalam penelitian ini adalah data primer dan data sekunder. Data Primer bersumber langsung di lokasi penelitian dimana perkawinan beda wangsa itu terjadi.

Data sekunder data dibedakan menjadi 3 (tiga) yaitu :

(a) bahan hukum primer, yaitu semua bahan atau materi hukum yang mempunyai kedudukan mengikat secara yuridis, meliputi peraturan perundang-undangan dalam hal ini undang-undang, peraturan daerah awig-awig

(b) bahan hukum sekunder, yaitu semua bahan hukum yang memberikan penjelasan terhadap bahan hukum primer,

(c) bahan hukum tersier, yaitu semua bahan hukum yang memberikan petunjuk atau penjelasan terhadap bahan hukum primer dan sekunder, meliputi majalah, kamus, dan Koran. ${ }^{8}$

\footnotetext{
Otong Rosadi, "Beberapa Catatan Terhadap Laporan Penelitian". Sumber : http://qbar. or.id/index.php.option.com.
} 


\subsection{Teknik Pengumpulan Data}

Teknik pengumpulan data primer dalam penelitian ini adalah dengan teknik wawancara dengan informan dan responden. Informan ditetapkan dengan teknik bola salju (snow ball) dimana ditentukan terlebih dahulu informan kunci. Dan informan kunci ini kemudian dimintakan rekomendasi mengenai informan/responden yang diperlukan. Dalam wawancara digunakan alat yang bernama pedoman wawancara (interview guide.

Data sekunder diproleh dari dokumen-dokumen resmi, buku-buku, hasil penelitian yang berwujud laporan serta peraturan yang berkaitan dengan permasalahan yang diteliti. Teknik pengumpulan data sekunder dilakukan dengan teknik pencatatan.

\subsection{Teknik Pengolahan dan Analisa Data}

Analisa data pada penelitian ini dilakukan secara kualitatif. Analisis data kualitatif adalah cara penelitian yang menghasilkan data deskriptif analisis yaitu apa yang dinyatakan oleh para responden pada lokasi penelitian, baik secara tertulis maupun lisan diteliti dan dipelajari secara utuh. Pengertian analisis disini, dimaksudkan sebagai suatupenjelasan danpenginterpretasian hasil-hasil penelitian yang berkaitan dengan bentuk perkawinan nyentana yang dilakukan oleh laki-laki berwangsa dengan perempuan yang tidak berwangsa.
Setelah analisis data selesai maka hasilnya disajikan secara deskriptif yaitu dengan menguraikan dan menggambarkan apa adanya sesuai dengan permasalahan yang diteliti. Dari hasil tersebut ditarik kesimpulan yang merupakan jawaban atas permasalahan yang diangkat dalam penelitian ini.

\section{HASIL DAN PEMBAHASAN \\ 3.1 Sejarah Kedudukan Hukum Suami-Istri dalam Perkawinan Nyentana Beda Wangsa \\ 3.1.1 Perkawinan Beda Wangsa Sebagai Bentuk Perkawinan Di Bali}

Ditinjau dari segi bentuk perkawinan di Bali, dikenal kemudian bentuk perkawinan keluar dan perkawinan ke dalam. ${ }^{9}$ Perkawinan keluartidaklainmerupakan perkawinan biasa, dimana mempelai wanita atau isteri meninggalkan keluarga asalnya dan masuk ke keluarga suami untuk melaksanakan seluruh aktifitas perkawinan. Adapun deskripsi dari perkawinan ke dalam adalah bertolak belakang dari penjelasan sebelumnya. Dalam hal ini mempelai laki-laki atau suami yang justru meninggalkan keluarga asalnya dan masuk ke keluarga isterinya guna melakukan seluruh aktifitas perkawinan. Bentuk perkawinan ini kemudian dikenal dengan istilah nyentana.

\footnotetext{
$9 \quad \mathrm{Ni}$ Nyoman Sukerti, 2012, Hak Mewaris Perempuan Dalam Hukum Adat Bali Kritis Sebuah Studi Kritis, Udayana University Press, Denpasar, hlm.35
} 
Dalam perkembangannya, dikenal pula bentuk perkawinan negen dadua atau perkawinan pada gelahang. Jika dalam perkawinan biasa, isteri menjadi milik keluarga suami dan di dalam perkawinan nyentana adalah suami yang menjadi milik keluarga isteri. Maka berbeda halnya dengan perkawinan pada gelahang yang berkonsekuensi bahwa suami-isteri adalah milik keluarga kedua belah pihak. ${ }^{10}$

Dahulu pada masyarakat di Bali dikenal penggolongan atau klasifikasi social secara ketat, sehingga timbul larangan untuk melaksanakan perkawinan pasangan yang berbeda strata sosial (incest rank social). ${ }^{11}$ Dalam hal ini yang peneliti maksud sebagai klasifikasi social adalah sistem kasta yang diperhalus dengan istilah wangsa. Larangan perkawinan beda wangsa tujuannya tidak lain adalah "pemurnian" (puritanisasi) wangsa, karena percampuran wangsa dalam perkawinan beda wangsa dianggap menimbulkan pencemaran dari sudut pandang tertentu. ${ }^{12}$ Jika dilihat dari sejarahnya, berdasarkan Paswaratahun 1910 yang kemudian diubah menjadi beslit Residen Bali dan Lombok No. 352, JI C.2 tanggal 19 April 1951dalam hokum adat Bali pernah $10 \quad$ Ibid, hlm. 37

11 DominikusRato, 2011, Hukum Perkawinandan WarisAdat (Sistem Kekerabatan, Bentuk Perkawinandan Pola Pewarisan Adat di Indonesia), Laksbang Yustisia Surabaya, Surabaya, hlm. 17

12 JiwaAtmaja, 2008, Bias Gender Perkawinan Terlarang Pada Masyarakat Bali, Udayana University Press, Denpasar, hlm. 150-151 dikenal ungkapan asupundung dana langkah ikarang hulu. Secara harafiah, asupundung berarti "menggendong anjing" dan alangkah ikarang hulu dapat diartikan "melompati kepala". ${ }^{13}$

Kedua ungkapan di atas mengandung makna bahwa hirarki sosial merupakan rambu bagi seseorang untuk dapat melaksanakan perkawinan. Seseorang dengan wangsa yang lebih tinggi tidak boleh kawin dengan wangsa yang lebih rendah. Jika perkawinan ini tetap dilaksanakan, maka segenap sanksi ikut menyertai, salah satunya patiwangi atau upacara yang bertujuan menurunkan atau mematikan wangsa pihak yang lebih tinggi. ${ }^{14}$ Tentang larangan perkawinan beda wangsa sebagaimana diuraikan tersebut, kemudian dihapus pada tahun 1951 berdasarkan Paswara DPRD No. 11 Tahun 1951 yang di latar belakangi oleh pertimbangan agar tidak terjadi diskriminasi terhadap suatu golongan wangsa. Hal ini telah bersesuaian substansi Pasal 18 B ayat (2) Undangundang Dasar Negara Republik Indonesia Tahun 1945, yang berbunyi sebagai berikut :

"Negara mengakui dan
menghormati kesatuan-kesatuan
masyarakat hukum adat beserta
hak-hak tradisionalnya sepanjang
masih hidup dan sesuai dengan
perkembangan masyarakat dan
prinsip negara kesatuan Republik
Indonesia yang diatur dalam
undang-undang."

Ibid, hlm. 148

$14 \quad$ Ibid, hlm. 177 
Dalam kalimat yang lebih disederhanakan, bahwa kesatuan masyarakat hukum adat dapat melaksanakan hukum adatnya terhadap warga, sepanjang norma dari hukum adat tersebut tidak bertentangan dengan peraturan perundang-perundangan yang berlaku secara nasional.

Ditinjau dari segi teori, yakniteori semi-otonom, maka masyarakat adat di Bali wajib mentaati Paswara DPRD No. 11 Tahun 1951 tersebut. Mengingat bahwa masyarakat hukum juga merupakan bagian dari suatu negara, sehingga norma yang dibentuk negara melalui pemerintah atau keputusan-keputusan administratif dan pengadilan tetapmenimpabidang sosial semi-otonom yang sebelumnya telah memiliki aturan dan adat kebiasaan sendiri. ${ }^{15}$ Berdasarkan pertimbangan secara normatif dan teoritis, maka pandangan masyarakat adat di Bali (paradigma) perihal perkawinan beda wangsa harus berubah. Dengan kata lain, persepsi masyarakat mengenai perbedaan wangsa dalam urusan perkawinan harus sejalan dengan perkembangan masyarakat yang telah diakomodir oleh peraturan perundangundangan yang berlaku. Apabila dalam prakteknya masih ada masyarakat adat di Bali yang melaksanakan perkawinan dengan mempertahankan prinsip wangsa, maka secara yuridis perkawinan tersebut tetap dianggap

15 T.O. Ihromi, 2001, Antropologi Huum Sebuah Bunga Rampai, Cet, ke-2, Yayasan Obor Indonesia, Jakarta, hml. 153, lihat juga Sally Falk moore dalam an Anthropological Approach sebagai perkawinan pada umumnya yang tidak sama sekali memuat urusan wangsa dan sanksi di dalamnya.

Mengenai perkawinan nyentana beda wangsa, bertalian dengan penjelasan sebelumnya maka mempelai laki-laki yang keluar dari keluarga asalnya dan kemudian masuk ke dalam rumpun keluarga mempelai wanita. Dengan demikian, idealnya kedua calon pengantin harus berasal dari wangsa yang sama atau sejajar. Namun pada kenyataannya tidak selalu demikian, adakalanya wangsa dari mempelai wanita yang justru lebih tinggi dibanding mempelai laki-laki, dan hal ini yang kerap menimbulkan permasalahan ditengah masyarakat.Perkawinan ini lah yang kemudian dapat digolongkan sebagai perkawinan asupundung dan alangkahi karang hulu yang pada awalnya merupakan suatu larangan. Pajaman dahulu terhadap pelaku perkawinan beda wangsa berlaku berbagai jenis hukuman, diantaranya labuh geni (dilemparkan ke dalam bara api), lebuh batu (ditenggelamkan hidup-hidup ke dalam laut, dengan terlebih dahulu diberi pemberat batu), penjatuhan sanksi selong (dibuang), denda sejumlah nominal tertentu dan patiwangi (diturunkan wangsa-nya). ${ }^{16}$

Setelah dikeluarkannya Paswara DPRD No. 11 Tahun 1951, maka secara yuridis perkawinan nyentana beda wangsa tidak lagi merupakan suatu larangan. Oleh karena itu setiap orang dapat melaksanakan perkawinan

16 Jiwa Atmaja, op.cit, hlm. 158-159 
tanpa terikat dengan urusan wangsa, sepanjang tidak bertentangan dengan apa yang diatur dalam Undang-undang tentang Perkawinan. Dengan demikian keabsahan perkawinan nyentana beda wangsa tidak perlu diragukan lagi dan pada prinsipnya perkawinan tersebut tetap dianggap sebagai perkawinan nyentana pada umumnya yang tidak sama sekali memuat urusan wangsa di dalamnya.

\subsubsection{Hak dan Kewajiban Suami- isteri Dalam Perkawinan Nyentana Beda Wangsa}

Perkawinan nyentana beda wangsa adalah perkawinan nyentana pada umumnya tanpa mengandung unsur wangsa yang cenderung bersifat diskriminatif. Berdasarkan kedudukan hukum suami-isteri dalam Undangundang tentang Perkawinan yang dikaitkan dengan sistem kerabatan patrilienal (kepurusha) di Bali, maka dapat diketahui kedudukan suami-isteri dalam perkawinan nyentana beda wangsa. Pada intinya perkawinan nyentana beda wangsa merupakan salah satu upaya yang dapat ditempuh bagi keluarga untuk melanjutkan kelangsungan keturunan jika tidak sama sekali memiliki anak laki-laki, di mana mempelai wanita (isteri) yang menarik mempelai lakilaki (suami) untuk keluar dari ikatan purusha-nya, sehingga isteri yang kemudian berkedudukan selaku purusha (berstatus laki-laki) di dalam perkawinan tersebut.
Vol. 5, No. $2: 301-320$

http://ojs.unud.ac.id/index.php/jmhu $\begin{array}{llr}\text { Secara } & \text { hukum (nasional) } \\ \text { kedudukan suami-isteri tidak } & \text { sum } \\ \text { mengalami perbedaan sedikit pun, } \\ \text { namun dalam konteks adat Bali }\end{array}$ justru mengakibatkan istri memiliki kedudukan yang lebih penting dibanding suami. Selain bertindak sebagai penerus keturunan, isteri juga bertanggung jawab penuh atas orang tua kandung dan leluhurnya serta sekaligus berkedudukan sebagai ahli waris yang berkewajiban untuk menjaga, mengelola dan meneruskan segenap harta pusaka guna kepentingan keturunannya.

Di samping itu, perkawinan pada masyarakat hukum adat di Bali juga berimplikasi pada tanggung jawab untuk ikut terlibat sebagai krama banjar. Ini yang kemudian dimaksud sebagai sistem mapikuren dalam sistem keanggotaan desa Pakraman. ${ }^{17}$ Pada prakteknya, meskipun perkawinan nyentana beda wangsa memposisikan istri sebagai purusha dan suami sebagai pradana tapi bukan berarti hal tersebut juga berlaku dalam hidup mebanjaran. Tanggung jawab sebagai sebagai karma banjar memposisikan suami tetap bertanggung jawab sebagai krama muani dan istri tetap bertanggung jawab dalam kapasitasnya sebagai krama luh.

Perkawinan nyentana beda wangsa dalam sudut pandang lainnya, khususnya dalam perspektif gender, dapat dikategorikan sebagai sebuah terobosan yang menjunjung tinggi

$17 \quad$ Ibid, hlm. 50 
usaha tentang pemberdayaan terhadap kaum wanita di tengah sistem kekerabatan patrilinieal yang sangat patriarki. Perlakuan diskriminasi terhadap wanita Bali seolah dapat dihapuskan, salah satunya dalam bidang waris. Dengan adanya bentuk perkawinan nyentana beda wangsa,maka terbuka peluang bagi wanita Bali untuk berkedudukan sebagai ahli waris atas harta pusaka milik keluarga.

\subsection{Budaya Hukum Masyarakat Tabananterhadap Perkawinan Nyentana Beda Wangsa}

\subsubsection{Perkawinan Nyentana Sebagai Budaya Bagi Masyarakat Adat di Tabanan}

Berkaitan dengan penelitian ini, terdapat informasi lain yang tidak kalah penting untuk di deskripsikan tentang kabupaten Tabanan, yakni perkawinan nyentana, mengingat bentuk perkawinan ini sangat umum ditemukan di Kabupaten Tabanan. Perkawinan ini bernuansa kebudayaan hindu-jawa yang diperkirakan mulai pada waktu kedatangan patih Gadjah Mada (sekitar Tahun 1343 Masehi). ${ }^{18}$ Bentuk perkawinan berdasarkan perubahan status sebagai purusha dari pihak wanita dan sebagai pradana dari pihak laki-laki, dalam pelaksanaannya

18 V.E. Korn, 2013, Bentuk-Bentuk Sentana Menurut Adat Bali Masa Kolonial, terjemahan I Gde Wayan Pangkat \& Mien Joebaar, Denpasar, hlm. 38-39 juga melalui empat (4) tahapan sebagaimana perkawinan biasa, yakni, meminta, mengambil, nyakapang, ngunya. ${ }^{19}$

Dalam melangsungkan perkawinan Nyentana Beda Wangsa juga harus memperhatikan Syarat syarat Perkawinan, yaitu sebagai berikut:

\section{a) Persetujuan kedua mempelai}

Undang-undang Perkawinan menegaskan beberapa syarat agar perkawinan dapat dilangsungkan. Syarat pertama adalah perkawinan harus didasarkan atas persetujuan kedua calon mempelai. Demikian bunyi Pasal 6 ayat (1) Undang-undang Perkawinan. Menurut penjelasan resminya, disamping syarat ini sesuai dengan hak asasi manusia, ketentuan ini diadakan untuk mendukung agar tujuan pekawinan, yaitu untuk membentuk keluarga yang kekal dan bahagia dapat dicapai.

\section{b) Ijin orang tua}

Syarat kedua adalah seperti disebutkan dalam Pasal 6 ayat (2). Disebutkan bahwa untuk melangsungkan perkawinan seorang yang belum mencapai umur 21 (duapuluh satu) tahun harus mendapat ijin kedua orang tua. Selanjutnya disebutkan dalam ayat (3) bahwa dalam hal salah seorang dari kedua orang tua telah meninggal dunia atau dalam keadaan tidak mampu menyatakan kehendaknya maka

19 Ida Bagus Anom, 2010, Perkawinan Menurut Adat Agama Hindu, CV. Kayumas Agung, Denpasar, hlm. 7 
izin dimaksud cukup diperoleh dari orang tua yang masih hidup atau dari orang tua yang mampu menyatakan kehendaknya. Dalam hal kedua orang tua telah meninggal dunia atau dalam keadaan tidak mampu menyatakan kehendaknya maka izin diperoleh dari wali, orang yang memelihara atau keluarga yang mempunyai hubungan darah dalam garis keturunan lurus ke atas selama mereka masih hidup dan dalam keadaan dapat menyatakan kehendaknya. Jika ada perbedaan pendapat antara orang-orang yang disebutkan di atas, atau salah seorang diantara mereka tidak menyatakan pendapatnya, maka berdasarkan ayat (4) pasal ini, Pengadilan dalam daerah hukum tempat tinggal orang yang akan melangsungkan perkawinan atas permintaan orang tersebut dapat memberikan ijin, setelah terlebih dahulu mendengar orang-orang tersebut di atas.

\section{c) Batas umur perkawinan}

Syarat ketiga yang tidak kalah pentingnya adalah mengenai batas umur untuk perkawinan. Berdasarkan Pasal 7, perkawinan hanya dizinkan jika calon mempelai pria sudah mencapai umur 19 (sembian belas) tahun dan calon mempelai wanita sudah mencapai umur 16 (enam belas) tahun. Penyimpangan terhadap ketentuan ini hanya dimungkinkan bila ada dispensasi dari Pengadilan atau pejabat lain yang ditunjuk oleh kedua orang tua pihak pria maupun perempuan. Menurut penjelasan resmi terhadap Pasal 7, penetapan batas usia untuk perkawinan ini dimaksudkan untuk menjaga kesehatan suami istri dan keturunan.

Bahwa untuk Perkawinan Beda Wangsa juga harus tunduk Pada Undang-Undang Perkawinan yang mengatur tentang Larangan Perkawinan. Undang-undang juga menetapkan larangan-larangan perkawinan. Pasal 8 menyebutkan bahwa perkawinan dilarang antara dua orang yang:

a) Karena berhubungan darah dekat, yang dimaksud dengan berhubungan darah dekat antara lain :

- berhubungan darah dalam garis keturunan lurus ke bawah atau ke atas;

- berhubungan darah dalam garis keturunan menyamping yaitu antara saudara, antara seorang dengan saudara orang tua dan antara seorang dengan saudara neneknya;

- berhubungan semenda yaitu mertua, anak tiri, menanru dan ibu/bapak tiri;

- berhubungan susuan yaitu orang tua susuan, anak susuan, saudara susuan dan bibi/paman susuan;

- berhubungan saudara dengan isteri atau sebagai bibi atau kemenakan dari istri, dalam hal seorang suami berisrri lebih dari seorang; 
- $\quad$ yang mempunyai hubungan yang oleh agamanya atau peraturan lain yang berlaku dilarang kawin.

b) Larangan perkawinan bagi pasangan yang telah bercerai dua kali

Salah satu perkawinan yang dilarang dalam Undang-undang Perkawinan adalah larangan perkawinan bagi pasangan yang telah bercerai dua kali. Dalam Pasal 10 disebutkan bahwa apabila suami dan istri yang telah cerai kawin lagi untuk kedua kalinya, maka diantara mereka tidak boleh dilangsungkan perkawinan lagi, sepanjang hukum masing-masing agama dan kepercayaan itu dari yang bersangkutan tidak menentukan lain.

c) Larangan poligami

Disamping larangan seperti disebutkan dalam Pasal 8 dan Pasal 10 di atas, undang-undang juga melarang poligami dan poliandri. Poligami artinya seorang suami beristri lebih dan seorang, sedangkan poliandri adalah apabila seorang perempuan bersuami lebih dari seorang. Pasal 9 Undangundang Perkawinan menyebutkan bahwa "sesorang yang masih terikat tali perkawinan dengan orang lain tidak dapat kawin lagi kecuali hal tersebut pada Pasal 3 ayat (2) dan Pasal 4 Undang-undang ini”. Pasal 3 ayat (2) dan Pasal 4 yang dimaksud adalah mengenai pengecualian dari asas poligami. Ketentuan di atas dapat dipandang sebagai larangan poligami atau poliandri, yang dalam masyarakat
Bali lazim disebut memadu. Pasal 9 merupakan penjabaran dari asas monogami yang dianut dalam Pasal 3 Undang-undang Perkawinan, yang selengkapnya menyebutkan bahwa "pada asasnya dalam suatu perkawinan seorang pria hanya boleh mempunyai seorang istri, seorang perempuan hanya boleh mempunyai seorang suami”.

Dari hasil survey yang dilakukan pada karma - karma desa dan kelian adat didesa tersebut (Ratu aji) mempaparkan dalam proses perkawinan nyentana yang melakukan proses berpamitan di pemerajan adalah mempelai laki-laki. Karena calon mempelai laki-lakilah yang akan meninggalkankeluarga dan leluhurnya, untuk ikut kedalam garis keturunan kelurga perempuan. Semenjak proses berpamitan kepada leluhur itu mempelai laki-laki menjadi hak dan tangungjawab kelurga perempuan. Dalam hal ini, mempelai laki-laki statusnya tidak lagi sebagai purusa (laki-laki), namun sebagai pradana (perempuan), sehingga mempelai lakilaki mengikuti istrinya untuk tinggal pada kelurga perempuan.

Pada perkawinan nyentana status perempuan telah diubah menjadi laki-laki yang dilakukan melalui prosesi upacara putrika sebelum diadakan perkawinan. Putrika artinya proses perbahan status dan kedudukan perempuan menjadi laki-laki melalui prosesi upacara adat yang harus disaksikan oleh tri saksi (tiga saksi) yaitu Tuhan, Leluhur dan 
masyarakat dan disetujui oleh kelurga serta dilegitimasi oleh perangkat desa adat. Jika kelurga putrika tidak menyetujui terjadinya prosesi putrika, maka prosesi putrika tidak boleh dilaksanakan. Hal ini berkaitan dengan peralihan kekayaan baik yang berupa benda materiil mapun yang berupa non materiil seperti sanggah dan leluhur.

Perempuan yang telah diputrika memiliki status dan kedudukan sebagai laki-laki sesuai dengan legitimasi adat yang telah diberikan kepadanya. Sehingga semenjak prosesi putrika tersebut ia memiliki hak dan tangung jawab untuk menjadi ahli waris dan meneruskan garis keturunan kelurganya. Secara otomatis semenjak terjadinya putrika ia juga memiliki tangungjawab sebagai kepala keluarga dan sebagai kepala rumah tangga. Sebagai kepala keluarga putrika juga mempunyaikewajibanuntukmemenuhi semua kebutuhan keluarganya, termasuk kebutuhan orangtuanya. Ia juga menjadi penentu setiap keputusan yang akan diambil oleh keluarga, berkaitan dengan permasalahan yang ada di keluarganya. Sedangkan lakikaki yang nyentana mempunyai tangungjawab dan kewajiban sebagaimana layaknya perempuan dalam rumah tangga. Ia membantu istri untuk menjalankan roda perekonomian keluarga serta mengurus anak-anak. Dalam mengambil keputusan yang berkaitan dengan keluarga ia mesti meminta persetujuan dari istrinya terlebih dahulu.
Vol. 5, No. $2: 301$ - 320

http://ojs.unud.ac.id/index.php/jmhu
Kondisi ini tidak terlepas dari adanya perubahan kewajiban dan tangungjawab yang sepenuhnya sudah ada pada pihak perempuan yang berstatus putrika. Sebagai ahli waris perempuan putrika mempunyai kewenangan "mutlak" berkaitan dengan harta kekayaan yang dimiliki oleh keluarga. Kewenangan ini dimiliki berkaitan dengan statusnya sebagai akhli waris dan penerus keturunan keluarga. Sehingga ia diberikan keleluasaan untuk melakukan tindakan yang bertujuan untuk memperbaiki kondisi keluarga.

Dalam fakta di lapangan, maka yang kemudian disesuaikan dengan informasi dari beberapa kepala dusun, maka dapat dideskripsikan bahwa perkawinan nyentana beda wangsa masih menyisakan sedikit permasalahan

1) Mengenai pengetahuan para pemuka adat (prajuru) dan krama adat lainnya tentang Paswara DPRD Tahun 1951. Berdasarkan hasil wawancara, hampir sebagaian besartidak mengetahui aturan yang secara tegas telah menghapuskan perkawinan beda kasta yang kerap menimbulkan diskriminasi.

2) Dalam ritual pelaksanaan perkawinan, bahwa terdapat perbedaan di setiap banjar, khususnya terkait pelaksanaan upacara patiwangi.

3) Terkait kehadiran manusa saksi, dalam hal ini yang dimaksud 
adalah bendesa adat dan kelihan adat. Pada hakekatnya kehadiran bendesaadatmaupunkelihanadat hanya sebatas menjalankan tugas administratif,yaknimenyaksikan dan mencatat dilangsungkannya suatu perkawinan yang dilakukan oleh masyarakatnya. Jika terjadi pro dan kontra dalam keluarga terhadap perkawinan tersebut tidak dipandang sebagai hambatan dan penyelesaiannya diserahkan ke intern keluarga masingmasing. Dengan demikian tidak ada tanggungjawab moril dari pemuka adat untuk meluruskan pemahaman yang keliru dan berujung pada perbedaan pendapat dari warganya terkait perkawinan nyentana beda wangsa.

4) Perihal respon masyarakat terhadap perkawinan nyentana beda wangsa. Masyarakat pada intinyajugatidakmemberirespon apapun terhadap perkawinan nyentana beda wangsa. Adapun pro dan kontra yang timbul dari intern keluarga dan berujung pada perlakuan yang melarang pemakaian nama wangsa, larangan dalam hal pelaksanaan persembahyangan, larangan nunas tirta (air suci), dibuang dari keluarga besar dan lain-lain, masyarakat di sekitar tidak ikut campur akan hal tersebut.
Vol. 5, No. 2 : 301 - 320

http://ojs.unud.ac.id/index.php/jmhu

5) Terkait dengan persoalan hak dan kewajiban di banjar. Mengingat perkawinan dalam hukum adat Bali tidak hanya berbicara tentang urusan privat, melainkan juga bagian dari urusan publik, khususnya tanggung jawab sebagai anggota atau krama banjar.

Berdasarkan penelusuran di lapangan, tidak terdapat perlakuan khusus bagi krama banjar dengan latar belakang perkawinan nyentana beda wangsa. Sebagai krama banjar, mereka berkedudukan setara dengan krama banjar lainnya, baik dari segi hak maupun kewajiban yang dipikul.

Berdasarkan fakta-fakta di atas, maka dapat disimpulkan bahwa sikap masyarakat adat di Tabanan terhadap perkawinan nyentana beda wangsa ialah tetap memandang perkawinan nyentana beda wangsa sebagai perkawinan antar kasta. Meskipun secara hukum perkawinan nyentana beda wangsa adalah sama dengan perkawinan nyentana pada umumnya, namun dengan latar belakang budaya hukum sebagaimana telah diuraikan di atas mengakibatkan perlakuan yang diskriminatif terhadap suami-istri yang melaksanakan perkawinan nyentana beda wangsa tetap berlangsung sebagai akibat isu pro dan kontra di intern keluarga yang bersangkutan. Ditambah dengan prilaku pemuka adat yang tidak pro aktif dalam menanggulangi aksi diskriminatif 
yang terjadi pada warganya yang melaksankan perkawinan nyentana beda wangsa.

Perkawinan nyentana beda wangsa perbedaan yang mencolok dengan perkawinan nyentana biasa adalah nama anak di dalam akte kelahiran anak, dimana nama anak yang tertera memakai nama yang mengikuti nama yang dipakai oleh istri pasangan yang menikah dengan bentuk perkawinan nyentana beda wangsa. Sehingga ini sering menjadi pertanyaan teman-teman di sekolah maupun pihak guru dimana anak pasangan yang menikah beda wangsa menempuh pendidikan.Di samping itu jika terjadi perceraian maka anak akan mengikuti garis keturunan ibu. Pada sistem kekerabatan patrilinial apabila terjadi perceraian maka pengasuhan anak-anak berada di tangan ayah dan keluarganya,kecualidalam perkawinan nyentanan atau nyeburin ${ }^{20}$

\section{PENUTUP}

\subsection{Simpulan}

Berdasarkan uraian sebelumnya, dapat ditarik kesimpulan sebagai berikut :

1. Secara hukum nasional, tidak terdapat perbedaan kedudukan suami-isteri dalam perkawinan nyentana beda wangsa. Namun dalam Hukum adat Bali, justru mengakibatkan

$20 \mathrm{Ni}$ Nyoman Sukerti, Penegakan Hukum Terhadap Hak asuh Anak Akibat Perceraian Dalam Praktik Peradilan Di Bali, Jurnal Magister Hukum Udayana, Volume IV No. 1 istri memiliki kedudukan yang lebih penting dibanding suami. Selain bertindak sebagai penerus keturunan, isteri juga bertanggung jawab penuh atas orang tua kandung dan leluhurnya serta berkedudukan sebagai ahli waris yang berkewajiban untuk menjaga, mengelola dan meneruskan segenap harta pusaka guna kepentingan keturunannya. Namun dalam kehidupan bermasyarakat, khususnya keterlibatan sebagai krama banjar, maka si suami tetap bertanggung jawab pada kewajibannya sebagai krama muani sedangkan si istri tetap berkedudukan sebagai krama luh.

2. Budaya hukum sebagian masyarakat hukum adat di Tabanan terhadap perkawinan nyentana beda wangsa ialah tetap berpandangan bahwa perkawinan tersebut merupakan perkawinan antar kasta. Oleh karenanya, saat ritual perkawinan berlangsung masih ada yang menyelenggarakan upacara patiwangi. Budaya hukum ini tetap bertahan dengan dilatarbelakangi oleh beberapa faktor, salah satu diantaranya ialah para pemuka adat maupun krama adat pada umumnya banyak yang tidak mengetahui Paswara DPRD No. 11 Tahun 1951 yang secara tegas telah 
menghapus perkawinan antar kasta yang kerap menimbulkan diskriminasi.

\subsection{Saran}

Bertolak dari kesimpulan sebelumnya, dapat dirumuskan saran sebagai berikut :

1. Sebagai upaya menjunjung tinggi usaha pemberdayaan terhadap kaum wanita di tengah sistem kekerabatan patrilinieal yang sangat patriarki sehingga dapat diimplementasikan dengan baik, maka masyarakat hukum adat di Tabanan diharapkan berkenan untuk merubah cara pandang tentang esensi perkawinan nyentana beda wangsa. Mengingat sistem kasta adalah sesuatu yang sangat tidak relevan dengan ajaran agama Hindu dan hukum di Indonesia, maka tidak ada alasan bagai para pihak yang berkepentingan untuk membatasi hak wanita di Bali untuk menentukan jodohnya berdasarkan kesetaraan dalam konteks kasta.

2. Agar spirit Paswara DPRD No. 11 Tahun 1951 dan Keputusan Pesamuhan Agung III MUDP tahun 2010 tentang Kedudukan Perempuan Dalam Hukum Adat, sebagai sarana rekayasa sosial dapat berjalan dengan maksimal, maka diharapkan peran aktif dari Parisadha Hindu Dharma dan Majelis Utama Desa Pakraman
Vol. 5, No. 2 : 301 - 320 http://ojs.unud.ac.id/index.php/jmhu

di Bali untuk mensosialisasikan tentang keberadaan Paswara DPRD No. 11 Tahun 1951 dan Keputusan Pesamuhan Agung III MUDP tahun 2010 tentang Kedudukan Perempuan Dalam Hukum Adat, yang secara tidak langsung menjunjung tinggi usaha pemberdayaan terhadap kaum wanita, dengan harapan aturan tersebut dapat dipahami dan ditaati oleh masyarakat hukum adat di Bali. Sehingga budaya hukum masyarakat kiranya dapat mengalami dinamika ke arah yang lebih baik.

\section{DAFTAR PUSTAKA}

\section{Buku}

A.A. GN Ari Dwipayana, 2004, Bangsawan dan Kuasa Kembainya Para Ningrat di Dua Kota, Cet. ke-1, IRE Press, Yogyakarta

Abdul Kadir Muhammad, 2004, Hukum Dan Penelitian Hukum, Penerbit PT. Citra Aditya Bhakti, Bandung.

Artadi , I Ketut, 1994, Hukum Adat Bali Dengan Aneka Permasalahannya, cet ke-5, Pustaka Bali Post, Denpasar. 2003, Hukum Adat Bali dan Aneka masalahnya, cet. 3, Pustaka Bali Post, Denpasar.

Badan Pusat Statistik Kabupaten Tabanan , 2013, Tabanan Dalam Angka 2013, Tabanan 
in Figures 2013, Arysta Jaya, Denpasar.

Budiana, I Nyoman, 2009, Perkawinan Beda Wangsa dalam Masyarakat Bali, Graha Ilmu, Yogyakarta.

Djaren Saragih, 1996, Pengantar Hukum Adat Indonesia, Tarsito, Bandung.

Dominikus Rato, 2011, Hukum Perkawinandan Waris Adat (Sistem Kekerabatan, Bentuk Perkawinandan Pola Pewarisan Adat di Indonesia), Laksbang Yustisia Surabaya.

Donny Gahral Adian, 2006, Percik Pemikiran Kontemporer Sebuah Pengantar Komprehensif, Jalasutra, Yogyakarta.

Griadhi, I Ketut Wirta, et all., 1992, "Perkawinan Nyeburin Berbeda Wangsa: Studi Antropologi Hukum Terhadap Kasus di Desa Wanasasri dan Desa Berembeng Kabupaten Tabanan", Laporan Penelitian, Universitas Udayana, Denpasar.

Hilman Hadikusuma, 1995, Metode Pembuatan Kertas Kerja atau Skripsi Ilmu Hukum, Mandar Maju, Bandung.

Ida Bagus Anom, 2010, Perkawinan Menurut Adat Agama Hindu, CV. Kayumas Agung, Denpasar.

Ihromi,T.O., 2001, Antropologi Huum Sebuah Bunga Rampai, Cet, ke-2, Yayasan Obor Indonesia, Jakarta.
Jiwa Atmaja, 2008, Bias Gender Perkawinan Tetrlarang Pada Masyarakat Bali, Cet. ke-1, Udayana University Press dan CV. Bali Media Adhikarsa, Denpasar.

Kembar Kerepun , Made, 2004, Benang Kusut Nama Gelar di Bali, Cet. ke-1, CV. Bali Media Adhikarsa, Denpasar.

, 2007, Mengurai Benang Kusut Kasta Membedah Kiat Pengajegan Kasta di Bali, PT. Empat Warna Komunikasi, Denpasar.

Korn, V.E., 1972, Hukum Adat Waris di Bali, terjemahan I Gde Wajan Pangkat, Fakultas Hukum \& Pengetahuan Masyarakat Universitas Udayana, Denpasar.

, 2013, Bentuk-Bentuk Sentana Menurut Adat Bali Masa Kolonial, terjemahan I Gde Wayan Pangkat \& Mien Joebaar, Udayana University Press, Denpasar.

Lawrence M. Friedman, 1975, The Legal System, A Social Science Perspective,

Rusell Sage Foundation, New York.

, 2009, Sistem Hukum Perspektif Ilmu Sosial, penerjemah : M. Khozim, Nusa Media, Bandung.

Mansour Fakih, 2008, Analisis Gender dan Transformasi Sosial, INSIST Press, Yogyakarta. 
Nico Ngani, 2012, Perkembangan Hukum Adat Indonesia, Pustaka Yustisia, Yogyakarta

Panetje, Gde, 2004, Aneka Catatan Tentang Hukum Adat Bali, cet ke-3, CV. Kayumas Agung, Denpasar.

Pasek Diantha, Made, Pasek Eka Wisanjaya I Gede, 2010, Kasta Dalam Perspektif Hukum dan HAM, Udayana University Press.

Prihatini Ambaretnani, N., 2010, Kekerasan Terhadap Perempuan Dalam Perspektif Antropologi. Dalam M. Munandar Sulaeman dan Siti Homzah., Editor. Kekerasan Terhadap Perempuan Tinjauan Dalam Berbagai Displin Ilmu \& Kasus Kekerasan, PT. Refika Aditama, Bandung.

Program Studi Magister Hukum (s2) Ilmu Hukum, 2013, Pedoman Penulisan Usulan Penelitian Tesis Dan Penulisan Tesis Studi Magister Hukum (s2) ilmu Hukum, Program Magister Universitas Udayana, Denpasar.

Rasjidi, Lili, Rasjidi, Ira, 2001, Dasar-dasar Filsafat dan Teori Hukum, Citra Aditya Bakti, Bandung.

Sara Sastra, 2005, Kala Badeg Sebuah Konsep Pendidikan Seks Pra Nikah Dalam Masyarakat Hindu, Paramita, Surabaya.
Satjipto Rahardjo, 2004, Sosiologi Hukum : Perkembangan Metode dan Pilihan Masalah, UMS Press, Surakarta.

Soepomo, R., 2003, Bab-Bab Tentang Hukum Adat, Cet-16, Jakarta, Pradnya Paramita.

Sudantra, Ketut, Sudiana,Ngurah, Narendra, Gede, 2011, Perkawinan Menurut Hukum Adat Bali, Udayana University Press, Denpasar.

Sukerti, Ni Nyoman, 2012, Hak Mewaris Perempuan Dalam Hukum Adat Bali Kritis Sebuah Studi Kritis, Udayana University Press, Denpasar.

Tjok Istri Putra Astiti, 2009, "Gender Dalam Persektif Budaya Bali", Pusat Studi Wanita Universitas Udayana Bekerjasama dengan Badan Pemberdayaan Perempuan dan Anak Provinsi Bali, Denpasar.

Tim Peneliti Fakultas Hukum Unud, 1988, "Laporan Penelitian Pengaruh Hukum Adat Waris Bali Terhadap Pola Norma Keluarga Kecil dan Bahagia dan Sejahtera", Kerjasama antara Univ. Udayana dengan Bappeda Tk I Prop. Bali 1997-1998.

Wiana, I Ketut, 2006, Memahami Perbedaan Catur Warna, Kasta dan Wangsa, Paramita, Surabaya.

Wiana, Ketut, Santeri,Raka, 2005, Kasta Dalam Hindu Kesalahpahaman Berabad- 
abad, Cet. ke-4, Yayasan Dharma Naradha, Denpasar.

Windia, Wayan P., Sudantra, Ketut,2006, Pengantar Hukum AdatBali,LembagaDokumentasi dan Publikasi Fakultas Hukum Universitas Udayana, Denpasar

Windia, Wayan P., dkk, 2009, Perkawianan Pada Gelahang di Bali, Udayana University Press, Denpasar.

Witanto,D.Y., 2012, Hukum Keluarga Hak dan Kedudukan Anak Luar Kawin Pasca Keluarnya Putusan MK Tentang Uji Materiil UU Perkawinan, Prestasi Pustakakarya, Jakarta.

Zainuddin Ali, H., 2008, Sosiolgi Hukum, Cet. Ke-3, Sinar Grafika, Jakarta

\section{Tesis}

Mangku, I Nyoman, 2010, "Pelaksanaan Perkawinan Nyeburin Beda Wangsa Menurut Hukum Adat Bali di Kabupaten Tabanan Provinsi Bali”, Tesis Program Magister Kenotariatan Universitas Udayana, Denpasar Sadnyini, Ida Ayu, 2000, "Dinamika

Hukum Adat dalam Perkawinan Asupundung di Bali”, (tesis) Program Studi Magister (S2) Ilmu Hukum Universitas Udayana Denpasar

Sri Susilowati, Nyoman, 2004, "Akibat Hukum Terhadap Perkawinan NyeburinAntar Wangsa Menurut Hukum Adat
Vol. 5, No. 2 : 301 - 320 http://ojs.unud.ac.id/index.php/jmhu

Bali“" Tesis Universitas Gadjah Mada, Yogyakarta

Suryatini, Ida Ayu Putu, 2003, "Kedudukam Hukum Anak Astra Setelah Orangtua Biologisnya Kawin Secaar Sah Menurut Hukum Adat Bali" (Studi Kasus Desa Sanur, Kecamatan Denpasar Selatan, Kota Denpasar, Daerah Tingkat I Bali), (tesis) Program Studi Magister (S2) Ilmu Hukum Universitas Diponegoro, Semarang

\section{Artikel}

Ni Nyoman Sukerti Dkk,Penegakan Hukum Terhadap Hak asuh Anak Akibat Perceraian Dalam Praktik Peradilan Di Bali, Jurnal Magister Hukum Udayana, Volume IV Nomor 1

Sudantra,I Ketut, 2007, ”Asupundung dan Alangkahi Karang Hulu Ketidakadilan Gender dalam Sistem Wangsa", Jurnal Studi Gender Srikandi, Volume VII Nomor 2

2013, Pengaruh Ideologi Gender Terhadap Perkembangan Hak Waris Perempuan Bali", Makalahpada Kegiatan : Sosialisasi Hasil Pesamuan Agung III MUDP Bali tentang Kedudukan Perempuan dalam Hukum Adat Bali Yang Diselenggarakan Oleh BadanKeluargaBerencana Dan PemberdayaanPerempuanKota Denpasar, 2013 


\section{Internet}

Otong Rosadi, "Beberapa Catatan Terhadap Laporan Penelitian”. Sumber : http://qbar.or.id/index. php.option.com 